\title{
PENGARUH PEMBERIAN PUPUK KANDANG SAPI TERHADAPPERTUMBUHAN DAN HASIL TANAMAN JAGUNG MANIS (Zea mays L)
}

\author{
Setiono, Azwarta \\ Program Studi Agroteknologi Fakultas Pertanian \\ Universitas Muara Bungo
}

Artikel Diterima 8 Oktober 2020, disetujui 2 Desember 2020

\begin{abstract}
ABSTRAK
Penelitian ini telah dilaksanakan di Desa Lubuk Punguk Kecamatan Jangkat Kabupaten Merangin, Penelitian ini dilaksanakan selama 4 bulan di laksanakan mulai dari tangga 101 Januari 2016 sampai dengan 15 April 2016. Tujuan penelitian ini adalah untuk mengetahui Pengaruh Pemberian Pupuk Kandang Sapi Terhadap Pertumbuhan dan Hasil Tanaman Jagung Manis (Zea mays L). Rancangan yang digunakan dalam penelitian ini adalah menggunakan Rancangan Acak Kelompok (RAK) dengan 5 perlakuan dan 4 ulanganyaitu K0:tanpa perlakuan, K1 : $300 \mathrm{~g} / \mathrm{lubang}$ tanaman setara dengan $3 \mathrm{~kg} /$ petak, $\mathrm{K} 2$ : $150 \mathrm{~g} / \mathrm{lubang}$ tanaman setara dengan $6 \mathrm{~kg} / \mathrm{petak}, \mathrm{K} 3: 450 \mathrm{~g} / \mathrm{lubang}$ tanaman setara dengan 9 $\mathrm{kg} /$ petak dan $\mathrm{K} 4$ : $600 \mathrm{~g} / \mathrm{lubang}$ tanaman setara dengan $12 \mathrm{~kg} /$ petak.

Hasil pengamatan dianalisis dengan menggunakan Statistik Analisis Ragam (Anova), apabila berpengaruh nyata maka dilanjutkan dengan uji Duncan New Multiple Range Tes't (DNMRT) pada taraf $5 \%$. Parameter yang diamati adalah tinggi tanaman $(\mathrm{cm})$, diameter batang (cm), jumlahdaun (helai) danBobot Segar Tongkol Bersih Pertanaman (g)

Dari hasil penelitian menunjukan bahwa Pemberian pupuk kandang sapi berpengaruh nyata terhadap tinggi tanaman $(\mathrm{cm})$, diameter batang $(\mathrm{cm})$, jumlah daun (helai) dan Bobot Segar Tongkol Bersih Pertanaman (g). Perlakuan terbaik yaitu K4 yaitu 600 g/lubang tanam.
\end{abstract}

Kata Kunci : PupukKandangSapi, PertumbuhandanHasilJagungManis

\section{PENDAHULUAN}

\section{Latar Belakang}

Luas lahan budidaya jagung manis di Kabupaten Merangin pada tahun 2013 sebesar 192 ha, dengan hasil produksi mencapai 1370 ton, dengan hasil rata-rata sebesar 7.1 ton/ha (BPS, Jambi 2014). Produksi ini masih sangat relatif rendah jika dibandingkan dengan produksi maksimal jagung manis varietas master sweet yang mampu mencapai 12.1 ton/ha (Suburintani 2013).

Berbagai upaya yang dapat dilakukan untuk meningkatkan produksi tanaman jagung manis di antaranya dengan melaksanakan program intensifikasi dan perluasan areal pertanaman. Program intensifikasi dapat dilakukan di antaranya dengan penambahan unsur hara melalui

pemupukan dengan tujuan meningkatkan hasil tanaman. Sedangkan perluasan areal penanaman jagung manis dapat dilakukan dengan memanfaatkan lahan yang ada.

Rendahnya hasil yang dicapai petani juga diduga karena kurangnya perhatian petani terhadap tingkat penerapan pemupukan yang tepat, baik organik, anorganik maupun pupuk hayati, atau rendahnya tingkat penerapan teknologi produksi lainnya, Kebutuhan hara tanaman jagung relatif sangat tinggi untuk mendukung laju pertumbuhan tanaman.

Di Kabupaten Merangin sebagian besar lahan kering yang ada didominasi 
jenis Ultisol.Tanah Ultisol di Kabupaten Merangi diperkirakan 1243 ha. (BPS Merangin, 2014).

Masalah utama dari tanah Ultisol ini adalah sifat fisik dan kimianya jelek.Usaha yang dapat ditempuh dalam mengatasi kendala sifat fisik dan kimia tanah yaitu dengan pemberian bahan organik.Keuntungan pemberian bahan organik ke dalam tanah di antaranya adalah dapat memantapkan agregat tanah, meningkatkan kandungan $\mathrm{N}, \mathrm{P}, \mathrm{K}$ serta meningkatkan kapasitas tukar kation.Penambahan pupuk kandang sapi memberikan keuntungan bagi pertumbuhan tanaman. Pupuk kandang sapi juga meningkatkan kemampuan tanah untuk menyimpan air yang nantinya berfungsi untuk mineralisasi bahan organik menjadi hara yang dapat dimanfaatkan langsung oleh tanaman selama masa pertumbuhannya (Sudartiningsih dan Prasetya, 2010)

Berdasarkan hasil penelitian Asroh, (2009) menyatakan bahwa pemberian pupuk kandang sapi 300g/tanaman dapat meningkatkan pertumbuhan dan hasil tanaman jagung manis, terutama jumlah daun hijau selama fase pengisian biji, mempercepat umur keluar malai dan tongkol serta meningkatkan hasil.

Penelitian bertujuan untuk mengetahui pengaruh pemberian pupuk kandang sapi terhadap pertumbuhan dan hasil jagung manis sekaligus untuk mengetahui dosis terbaik pemberian pupuk kandang sapi terhadap pertumbuhan dan hasil tanaman jagung manis.

Dari uraian latar belakang diatas maka penulis tertarik untuk melakukan penelitian dengan judul "Pengaruh Pemberian Pupuk Kandang Sapi Terhadap Pertumbuhan dan Hasil Tanaman Jagung Manis (Zea maysL).

\section{METODOLOGI PENELITIAN}

Penelitian ini telah dilaksanakan di Desa Lubuk Punguk Kecamatan Jangkat Kabupaten Merangin, yang terletak pada ketinggian tempat 1200 meter dari permukaan laut, dengan $\mathrm{pH}$ rata-rata 5,4 dan jenis tanah ultisol (Monografi Desa Lubuk Punguk, 2014).

Penelitian ini dilaksanakan selama 4 bulan yang akan dilaksanakan muli dari tanggal 01 Januari 2016 sampai dengan 15 April 2016.

Alat yang digunakan dalam penelitian ini adalah meteran, cangkul, ember, timbangan elektrik, alat tulis, sprayer jarring pagar, dan sendok sekop.

Bahan-bahan yang digunakan dalam penelitian ini adalah benih jagung varietas master sweet, (ZA, SP36, dan $\mathrm{KCl}$ ), danpupuk kandang sapi.

\subsection{Rancangan Percobaan}

Percobaan ini dilaksanakan dengan menggunakan Rancangan Acak Kelompok (RAK) dengan 5 perlakuan dan 4 kelompok. Sebagai perlakuan pupuk kandang sapi yang terdiri dari 5 taraf perlakuan :

K0 : Tanpa Perlakuan pupuk kandang sapi

$\mathrm{K} 1$ : $150 \mathrm{~g} / \mathrm{lubang}$ tanaman setara dengan $3 \mathrm{~kg} /$ petak

$\mathrm{K} 2: 300 \mathrm{~g} / \mathrm{lubang}$ tanamansetara dengan 6 $\mathrm{kg} / \mathrm{petak}$

K3 : 450 glubang/tanaman setara dengan $9 \mathrm{~kg} / \mathrm{petak}$

$\mathrm{K} 4: 600 \mathrm{~g} / \mathrm{lubang}$ tanaman setara dengan $12 \mathrm{~kg} /$ petak

Pemberian perlakuan dilakukan setelah persiapan lahan sudah selesai, dengan cara mengaduk secara merata pada lubang tanamsesuai dengan perlakuan yang telah ditetapkan. Pemberian perlakuan dilaksanakan satu minggu sebelum tanam.

Penanaman dilakukan setelah bedengan ditugal dengan kedalaman $5 \mathrm{~cm}$, selanjutnya memasukkan be 2benih tiap lubang tanam dengan jarak tanam 30 X 60 $\mathrm{cm}$. Setelah benih dimasukkan tutup kembali lubang tanam dengan media tanah yang diambil dari sekitar bedengan.

Perawatan yang dilakukan berupa penyiraman, pemupukan dasar, penyisipan, penjarangan, penyiangan dan Pencegahan hama dilakukan dengan cara menyemprotkan sevin pada lubang tanam dengan dosis 2 gr/liter air hal ini dilakukan 
untuk menghalau semut pada fase awal. Untuk mengendalikan jamur maupun penyakit dilakukan dengan cara menyemprotkan larutan dethane M-45.

Adapun Parameter yang Diamati adalah berupa tinggi tanaman $(\mathrm{cm})$, diameter batang $(\mathrm{cm})$, jumlah daun (helai), dan bobot segar tongkol bersih pertanaman (g).

Hasil pengamatan dianalisis secara statistik dengan menggunakan sidik ragam apabila terdapat pengaruh nyata maka dilanjutkan dengan uji Duncan New Multiple Range Test (DNMRT) pada taraf $5 \%$ (Steel and Torris, 1994).

\section{HASIL DAN PEMBAHASAN}

\section{Rataan Tinggi Tanaman $(\mathrm{cm})$}

Hasil analisis ragam (Anova) menunjukkan bahwa perlakuan pupuk kandang sapi berpengaruh sangat nyata terhadap tinggi tanaman jagung manis (lampiran 5a). Rataan tinggi tanaman jagung manis menurut perlakuan pemberian pupuk kandang sapi dapat dilihat pada Tabel 1.

Tabel 1. Rataan Tinggi Tanaman $(\mathrm{cm})$ dengan Perlakuan Pupuk Kandang Sapi

\begin{tabular}{|c|c|}
\hline Perlak & $\begin{array}{c}\text { Tinggi Tanaman } \\
(\mathbf{c m})\end{array}$ \\
\hline K0 & $126,49 \mathrm{~b}$ \\
\hline K1 & $126,97 \mathrm{~b}$ \\
\hline $\mathrm{K} 2$ & $128,15 \mathrm{~b}$ \\
\hline K3 & $139,93 \mathrm{a}$ \\
\hline K4 & $139,11 \mathrm{a}$ \\
\hline \multicolumn{2}{|l|}{$\mathrm{KK}=2,43 \%$} \\
\hline Keterangan & $\begin{array}{l}\text { :Angka-angka yang diikuti } \\
\text { oleh huruf kecil yang berbeda } \\
\text { pada kolom yang sama } \\
\text { menunjukkan berbeda nyata } \\
\text { menurut DNMRT pada taraf } \\
5 \% \text {. }\end{array}$ \\
\hline
\end{tabular}

Dari Tabel 1 diatas dapat dijelaskan bahwa perlakuan kontrol (K0), tidak berbeda dengan pemberian perlakuan pupuk kandang sapi $150 \mathrm{~g} / \mathrm{lubang}$ tanam (K1) dan pemberian perlakuan 300 g/lubang tanam (K2) akan tetapi berbeda dengan pemberian perlakuan $450 \mathrm{~g} / \mathrm{lubang}$ tanam (K3) dan $600 \mathrm{~g} /$ lubang tanam (K4). Perlakuan terbaik terdapat pada pemberian pupuk kandang sapi $450 \mathrm{~g} / \mathrm{lubang}$ tanam dengan rataan tinggi tanaman 139, $93 \mathrm{~cm}$. Hal ini diduga Ketersediaan unsur hara dalam tanah, struktur tanah, tata udara yang baik sangat mempengaruhi pertumbuhan dan perkembangan akar serta kemampuan akar dalam menyerap unsur hara unsur hara akan diserap oleh akar ditıntukan oleh semua faktor yang ...mmpengaruhi ketersediaan unsur hara sampai unsur hara tersebut berada dipermukaan akar sehingga mempengaruhi pertumbuhan, perkembangan dan hasil tanaman.

Syekhfani, (2011) menyatakan bahwa kandungan unsure hara yang terdapat didalam pupuk kandang sapi yakni $\mathrm{N} 2,33 \%$, P2O5 0,61 \%, K2O 1,58 $\%$.Winarso, (2011) menyatakan peran unsur hara $\mathrm{N}$ berfungsi untuk pertumbuhan tanaman dari sifat kerdil selanjutnya $\mathrm{P}$ berfungsi untuk diperlukan pada stadia awal pertumbuhan untuk meningkatkan perkembangan akar, pembentukan anakan, dan mempercepat tanaman berbunga sedangkan $\mathrm{K}$ sendiri berfungsi untuk diperlukan untuk memperkuat dinding sel tanaman dan berperan memperluas kanopi daun untuk proses fotosintesis pada tanaman.

Nugroho, dkk, (2009) menyatakan jagung manis merupakan tanaman yang perlu unsur hara khususnya $\mathrm{N}$ dalam jumlah cukup selama pertumbuhannya.Dengan kecukupan $\mathrm{N}$ selama pertumbuhan, maka daun-daun tua dibagian bawah tanaman tidak perlu menstrasfer kebutuhan nutrisinya ke daundaun muda yang baru tumbuh, yang pada akhirnya akan meningkatkan laju fotosintesa. Hal ini didukung oleh Gardner et al.(2006), bahwa adanya nutrisi yang cukup memungkinkan daun muda maupun tua memenuhi kebutuhan nutrisinya, dan nutrisi yang terbatas lebih sering didistribusikan ke daun-daun muda, sehingga mengurangi laju fotosintesa pada daun yang tua. 


\section{Rataan Diameter Batang (cm)}

Hasil analisis ragam (Anova) menunjukkan bahwa perlakuan pupuk kandang sapi berpengaruh sangat nyata terhadap diameter batang tanaman jagung manis (lampiran 6a). Rataan diameter batang tanaman jagung manis menurut perlakuan pemberian pupuk kandang sapi dapat dilihat pada Tabel 2 .

Tabel 2. Rataan Diameter Batang (cm) dengan Perlakuan Pupuk Kandang Sapi

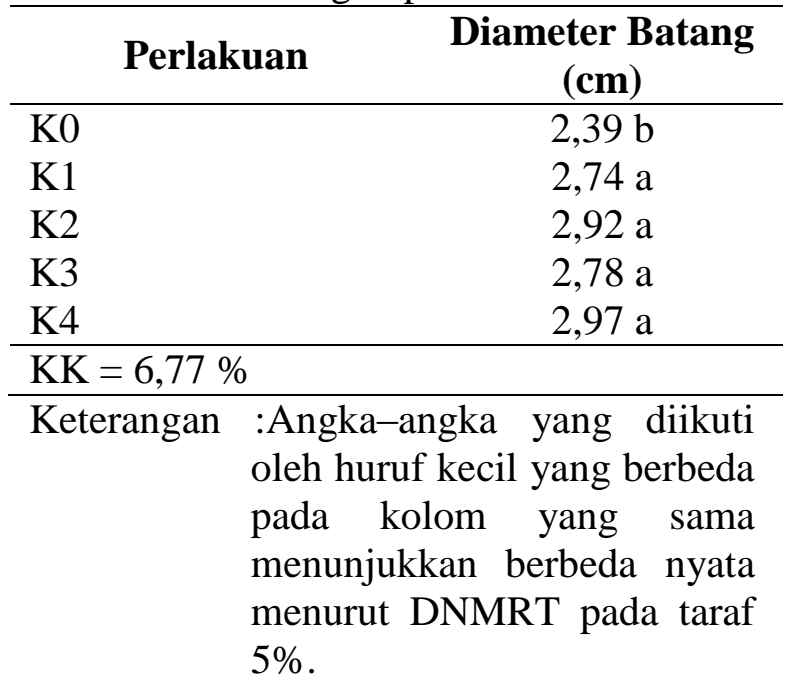

Pada Tabel 2 dapat dijelaskan bahwa tanpa pemberian perlakuan (K0) berbeda dentgan pemberian perlakuan pupuk kandang sapi $150 \mathrm{~g} / \mathrm{lubang}$ tanaman (K1), 300 g/lubang tanaman (K2), 450 glubang /tanaman (K3) dan pemberian perlakuan $600 \mathrm{~g} /$ lubang tanaman (K4). Pada perlakuan (K1) tidak berbeda dengan perlakuan (K2), (K3) dan (K4) sehingga dapat disimpulkan bahwa perlakuan terbaik terdapat pada pemberian pupuk kandang $150 \mathrm{~g} /$ lubang tanaman (K1) dengan rataan diameter batang $2,74 \mathrm{~cm}$. Bagi tanaman pupuk digunakan untuk hidup, tumbuh dan berkembang sehingga pemberian pupuk kandang sapi didugaberfungsi mendukung pertumbuhan diameter batang bersama unsur-unsur lain dalam tanah. Pupuk sangat dibutuhkan oleh tanaman untuk itu ketersediaan pupuk yang seimbang dalam tanah sangatlah diperlukan,
Menurut Mamonto (Sudartiningsih dan Prasetya. 2010) bahwa pupuk kandang sapi mengandung unsur hara NPK yang sangat dibutuhkan untuk merangsang pembesaran diameter batang serta pembentukan akar yang akan menunjang berdirinya tanaman disertai pembentukan tinggi tanaman pada masa penuaian atau masa panen. Disamping itu, faktor cahaya matahari yang tidak merata karena ternaungi menyebabkan pertumbuhan tinggi tanaman terhambat.

(Nyakpa dkk,2008).Nitrogen adalah unsur yang sangat penting bagi perkembangan diameter batang. Nitrogen merupakan bagian dari protein, bagian penting dari protoplasma, enzim, agen katalis biologis yang mempercepat proses kehidupan. Fosfor merupakan salah satu unsur hara makro yang esensial bagi pertumbuhan dan hasil tanaman, yang berperan penting dalam memacu terbentuknya karbohidrat dimana karbohidrat yang tercukupi akan mempengaruhi pembesaran sel dimana hasil aktifitas pembesaran sel akan berakibat pada meningkkatnya ukuran diameter batang, Peranan utama Kalium bagi tanaman adalah sebagai aktivator berbagai enzim yang berperan dalam proses metabolisme.Kalium merupakan salah satu unsur hara penting bagi tanaman sebab berperan sebagai katalisator dalam berbagai reaksi enzimatik di dalam tubuh jaringan tanaman sehingga menghasilkan pembesaran dinding sel.

Bahan organik juga memiliki poripori makro dan mikro yang hampir seimbang sehingga sirkulasi udara yang dihasilkan cukup baik serta memiliki daya serap air yang tinggi. Penyerapan dan translokasi air yang tinggi dalam tubuh tanaman akan memicu pembelahan sel dan pelebaran dinding sel sehingga sangat berpengaruh terhadap bertambahnya diameter batang (Prasetyo, 2008).

Ketersediaan hara dalam tanah, struktur tanah dan tata udara tanah yang baik sangat mempengaruhi pertumbuhan dan perkembangan akar serta kemampuan 
akar tanaman dalam menyerap unsur hara.Perkembangan sistem perakaran yang baik sangat menentukan pertumbuhan vegetatif tanaman yang pada akhirnya menentukan pula fase reproduktif dan hasil tanaman. Pertumbuhan vegetatif yang baik akan menunjang pembelahan sel yang berakibat pada bertambahnya ukuran batang Rinsema (2006).

Nyakpa $d k k$, (2008) menyatakan bahwa pupuk kandang termasuk dalam pupuk organik yang mempunyai peran sangat penting bagi tanaman karena mempunyai pengaruh yang positif terhadap sifat fisik dan kimiawi media yaitu dapat menaikkan daya serap media terhadap air dan menaikkan kondisi kehidupan mikro organisme dalam media sehingga mampu merangsang granulasi serta menyumbangkan ion-ion hara tersedia sehingga mampu memicu pertumbuhan dinding sel yang akan meningkatkan ukuran diameter batang.

\section{Rataan Jumlah Daun (helai)}

Hasil analisis ragam (Anova) menunjukkan bahwa perlakuan pupuk kandang sapi berpengaruh sangat nyata terhadap jumlah daun tanaman jagung manis (lampiran 7a). Rataan jumlah daun tanaman jagung manis menurut perlakuan pemberian pupuk kandang sapi dapat dilihat pada Tabel 3 .

Tabel 3. Rataan Jumlah Daun (helai) dengan Perlakuan Pupuk Kandang Sapi

\begin{tabular}{|c|c|c|}
\hline \multicolumn{2}{|c|}{ Perlakuan } & $\begin{array}{c}\begin{array}{c}\text { Jumlah Daun } \\
\text { (helai) }\end{array} \\
\end{array}$ \\
\hline K0 & & $15,97 \mathrm{~b}$ \\
\hline K1 & & $15,87 \mathrm{~b}$ \\
\hline $\mathrm{K} 2$ & & $15,80 \mathrm{~b}$ \\
\hline K3 & & $19,47 \mathrm{a}$ \\
\hline K4 & & $18,92 \mathrm{a}$ \\
\hline \multicolumn{3}{|c|}{$\mathrm{KK}=7,19 \%$} \\
\hline \multicolumn{3}{|c|}{$\begin{aligned} & \text { Keterangan } \text { :Angka-angka yang diikuti } \\
& \text { oleh huruf kecil yang berbeda } \\
& \text { pada kolom yang sama } \\
& \text { menunjukkan berbeda nyata } \\
& \text { menurut DNMRT pada taraf } \\
& \\
& 5 \%\end{aligned}$} \\
\hline
\end{tabular}

Dari Tabel diatas dapat dijelaskan bahwa perlakuan control (K0) tidak berbeda dengan pemberian perlakuan 150 g/lubang tanam (K1) dan 300 g/lubang tanaman (K2), akan tetapi berbeda dengan perlakuan 450 glubang /tanaman (K3) dan $600 \mathrm{~g} / \mathrm{lubang}$ tanaman. Pada perlakuan (K3) tidak berbeda dengan (K4) sehingga perlakuan terbaik terdapat pada pemberian pupuk kandang sapi $600 \mathrm{~g} / \mathrm{lubang}$ tanaman (K3) dengan jumlah daun 19,47 helai. Jumlah daun terbanyak terdapat pada tanaman tertinggi, hal ini dikarenakan daun tumbuh di setiap ruas batang tanaman, dimana semakin tinggi tanaman maka jumlah daunnya pun semakin banyak hal ini sejalan dengan pendapat sugito (2009), yang menyatakan kandungan klorofil yang tinggi dan permukaan daun yang lebih luas mengandung klorofil yang lebih banyak diakibatkan peningkatan produksi auksin yang terkandung didalam pupuk kandang sapi selanjutnya distribusi auksin yang terjadi di didalam tanaman mengakibatkan pemanjangan sel lebih cepat dan menghasilkan pertumbuhan tanaman dimana semakin tinggi tanaman akan semakin bertambah jumlah daunya yang akan menempati ruas-ruas pada batang tanaman jagung.

Kalium yang terdapat pada pupuk kandang sapi termasuk unsur hara esensial setelah N. Kalium pada tanaman terlibat dalam aktivitas fotosintesis melalui perannya dalam memacu proses membuka dan menutupnya stomata. Pembukaan stomata diakibatkan oleh banyaknya ion $\mathrm{K}+$ yang terdapat di dalam sel penjaga sehingga dapat mengakibatkan turunnya potensial osmotik dan diikuti dengan meningkatnya tekanan turgor sel. Selanjutnya Kadir dan Karo, (2006), menyatakan bahwa sehubungan dengan hal tersebut, untuk tanaman yang ketersediaan $\mathrm{K}$ cukup, aktivitas fotosintesisnya akan berjalan optimal, yang selanjutnya berdampak pada laju fotosintat yang dihasilkan.

Fotosintat merupakan karbohidrat sederhana yang berfungsi sebagai energi 
pertumbuhan.Oleh karenanya apabila kandungan $\mathrm{K}$ tanaman cukup optimum dalam tanah, menyebabkan meningkatnya energi untuk pertumbuhan.jumlah dan luas daun total (Sugito, 2009).

\section{Rataan Berat Tongkol Bersih per Tanaman (g)}

Hasil analisis ragam (Anova) menunjukkan bahwa perlakuan pupuk kandang sapi berpengaruh sangat nyata terhadap berat tongkol bersih pertanaman jagung manis (lampiran 8a). Rataan berat tongkol bersih per tanaman jagung manis menurut perlakuan pemberian pupuk kandang sapi dapat dilihat pada Tabel 4.

Tabel 4. Rataan Berat Tongkol Bersih per Tanaman (g) dengan Perlakuan Pupuk Kandang Sapi

\begin{tabular}{lc}
\hline Perlakuan & $\begin{array}{c}\text { Berat Tongkol } \\
\text { Bersih per } \\
\text { Tanaman }(\mathbf{g})\end{array}$ \\
\hline K0 & $106,88 \mathrm{~d}$ \\
K1 & $114,35 \mathrm{~d}$ \\
K2 & $134,99 \mathrm{c}$ \\
K3 & $163,02 \mathrm{~b}$ \\
K4 & $197,22 \mathrm{a}$ \\
\hline KK =8,40 \% & \\
\hline Keterangan & :Angka-angka yang diikuti \\
& oleh huruf kecil yang berbeda \\
& pada kolom yang sama \\
& menunjukkan berbeda nyata \\
& menurut DNMRT pada taraf \\
& 5\%.
\end{tabular}

Dari Tabel 4 diatas dapat dijelaskan bahwa perlakuan kontrol (K0) tidak berbeda dengan perlakuan 150 g/lubang tanaman (K1), akan tetapi berbeda dengan perlakuan $300 \mathrm{~g} / \mathrm{lubang}$ tanaman (K2), 450 glubang /tanaman (K3) dan perlakuan 600 g/lubang tanaman (K4). Pada perlakuan (K2) berbeda dengan perlakuan (K3) dan (K4), pada perlakuan (K3) berbeda dengan perlakuan (K4) sehingga perlakuan terbaik terdapat pada perlakuan (K4) dengan pemberian pupuk kandang sapi 600 g/lubang tanaman dengan hasil berat tongkol bersih per tanaman 197,22 g.Hal ini terbukti bahwa pemberian pupuk kandang sapimampu memperbaiki kondisi fisik, biologi dan kimia tanah tempat penelitian berlangsung, sehingga perlakuan yang diberikan dapat dimanfaatkan dengan baik oleh tanaman, selain juga pelepasan hara yang dikandung pupuk kandang sapi mampu menyumbangkan nutrisi bagi tanaman, sehingga pemberian $600 \mathrm{~g} / \mathrm{lubang}$ tanaman merupakan perlakuan terbaik dalam meningkatkan Berat Tongkol Berrsih per Tanaman.

Tanah yang subur dan banyak mengandung bahan organik tanah dapat memberikan produktivitas yang optimal bagi pertumbuhan dan perkembangan tanaman.Salah satu bahan organik yang baik berasal dari pupuk kandang yang didefinisikan sebagai semua produk buangan dari binatang peliharaan yang dapat digunakan untuk menambah hara, memperbaiki sifat fisik, dan biologi tanah (Hartatik dan Widowati, 2010).

Nugroho, Basuki dan Nasution (1999), menyatakan bahwa peningkatan bobot tongkol pada tanaman jagung manis seiring dengan meningkatnya efisiensi proses fotosintesis maupun laju translokasi fotosintat ke bagian tongkol. Perlakuan (K4) mempunyai laju fotosintesis dan produk biomasa (bobot kering tanaman) yang tinggi karena dengan tersedianya $\mathrm{N}$ dalam jumlah cukup akan mempercepat pengubahan gula heksosa untuk mengalami polimerisasi menjadi tepung dan komponen struktural seperti sellulose, hemisellulose, dll, dan bisa juga dirubah menjadi polisakarida (sebagai cadangan makanan) atau sukrose yang terbentuk segera masuk ke sistem pernafasan sel dan dibongkar untuk menghasilkan energi guna perkembangan dan pembesaran tongkol serta pengisian biji.

Dengan pemberian pupuk kandang sapi yang terkandung unsur $\mathrm{N}$ yang cukup, maka pertumbuhan organ-organ tanaman akan sempurna dan fotosintat yang terbentuk akan meningkat, yang pada akhirnya mendukung produksi tanaman. 
KESIMPULAN DAN SARAN

\section{Kesimpulan}

1. Pemberian pemberian pupuk kandang sapi berpengaruh nyata terhadap tinggi tanaman $(\mathrm{cm})$, diameter batang $(\mathrm{cm})$, jumlah daun(g) dan bobot bersih tongkol per tanaman $(\mathrm{g})$.

2. Perlakuan terbaik terdapat pada perlakuan $\mathrm{K} 4$ dengan pemberian pupuk kandang sapi 600 g/lubang tanaman mampu menghasilkan berat tongkol bersih per tanaman sebesar 197,29 gr.

\section{Saran}

Diharapkan penelitian ini dapat menjadikan sumber pengetahuan dan rujukan bagi petani yang akan melaksanakan budidaya tanaman jagung manis, dengan menggunakan pupuk kandang sapi pada dosis 600 g/lubang tanaman

\section{DAFTAR PUSTAKA}

Adisarwanto, T. dan Y.E. Widyastuti. 2010. MeningkatkanProduksi Jagung DiLahan Kering, Sawah dan Pasang Surut. Penebar Swadaya. Jakarta.

Asroh.A. 2009.Pengaruh Pemberian Pupuk Kandang Sapi Terhadap Pertumbuhan dan Hasil Tanaman Jagung Manis.Fakultas Pertanian.Batu Raja.

Apriyantono. A. 2011. Deskripsi jagung manis varietas Bonanza F1. Kementerian Pertanian. Jakarta.

Suburintani. 2013.Deskripsi Jagung Manis Varietas Master Mutiara. PT.Benih Inti. Jakarta.

Dahlan, F.H. dan Kaharuddin. 2007. Pengaruh penggunaan pemberian pupuk bokashi kotoran sapi terhadap pertumbuhan dan produksi tanaman jagung. Jurnal Agronomi.
Dartius. 2013. Fisiologi Tanaman 2. Fakultas Pertanian Universitas Sumatera Utara. Medan.

Gardner, F.P., R.B. Pearce dan R.L. Mitchell, $2006 . \quad$ Fisiologi Tanaman Budidaya. Universitas Indonesia. Jakarta

Ginting. 2010. Budidaya Jagung. Fakultas Pertanian Universitas Sumatera Utara. Medan.

Hartatik, W. dan L.R. Widowati, 2010. Pupuk Kandang Deptan. Jakarta

Hardjowigeno. 2013. Unsur Hara Esensial. PT. Mediatama Sarana Perkasa. Jakarta.

Jambi Dalam Angka. 2014. Badan Pusat Statistik Provinsi Jambi. Dinas Pertanian Tanaman Pangan. Jambi.

Kadir, S. dan Karo, MZ (2006), Pengaruh pupuk Kandang terhadap pertumbuhan dan Hasil Tanaman Jagung.

Marbun, B, E., 2006. Pupuk dan Pemupukan. Fakultas Pertanian Universitas Sumatera Utara. Medan.

Mardianto. 2009. Pupuk dan Cara Pemupukan. Bina Cipta. Jakarta.

Martajaya, M., L. Agustina dan Syekhfani. 2009. Pertumbuhan dan Hasil Jagung Manis (Zea mays Saccharata Sturt) yang Dipupuk Beberapa Macam Pupuk Organik pada Saat yang Berbeda.Agro J. Ilmiah Budidaya Pertanian Institut Pertanian Bogor.Bogor.

Nugroho, A., N.Basuki dan M.A. Nasution, 2009. Pengaruh Pemberian Pupuk Kandang dan Kalium Terhadap 
Kualitas Jagung Manis pada Lahan

Kering. Universitas Jambi.

Nyakpa, Y.M., A.A. Lubis, M.A. Pulung, A.G. Amrah, A. Munawar, Go Ban Hong dan N. Hakim. 2008. Kesuburan Tanah. Unila, Lampung.

Prasetyo, M.2008. Petunjuk Penggunaan Pupuk, Redaksi Agromedia. Jakarta

Rinsema, W.T. 2006.Pupuk dan Cara Pemupukan Kompos Bokasi Pupuk Kandang.Bhatara. Jakarta.

Sarief, E.S. 2013.Pupuk dan Cara Pemupukan. Bhatara Karya Aksara. Jakarta

Sudartiningsih, D., dan B. Prasetya. 2010. Pengaruh pemberian pupuk pupuk " organik diperkaya" terhadap ketersediaan dan serapan $\mathrm{N}$ serta produksi cabai besar (Capsicum annuum L.) pada tanah Inceptisol Karangploso Malang.

Sugito.2009. Kajian Pertumbuhan dan Produksi Pada Tanaman Jagung 8 Merril Di Lahan Sawah Tadah Hujan.Jurnal Ilmu-Ilmu Pertanian. Universitas Gadjah Mada. Jokjakarta.

Syekhfani. 2011. Arti Penting Bahan Organik Bagi Kesuburan Tanah. Konggres Idan Semiloka Nasional.MAPORINA. Batu, Malang.

Tohari,. 2006. Fisiologi Tanaman Budidaya Tropik. Gadjah Mada University Press, Yogyakarta.

Winarso, S. 2011. Kesuburan Tanah Dasar Kesehatan dan Kualitas Tanah. Yogyakarta: Gava Media 